\title{
Detection of human cytomegalovirus DNA in paraffin sections of human brain by polymerase chain reaction and the occurrence of false negative results
}

\author{
P Gass, M Kiessling, P Schäfer, C Mester, H P Schmitt, J E Kühn
}

\begin{abstract}
Paraffin-embedded necropsy material from 6 patients with human cytomegalovirus encephalitis (HCMVE) corroborated by immunocytochemistry and 11 control cases were examined for the presence of human cytomegalovirus (HCMV) DNA by a nested polymerase chain reaction (nPCR). A characteristic 183 base pair (bp) fragment of the HCMV genome could readily be amplified in 4 cases of HCMVE. In 2 cases of HCMVE, viral DNA could be demonstrated only sporadically by PCR, due most likely to inefficient DNA extraction or DNA degradation. All control cases remained negative. The nPCR provides a specific method for detecting HCMV DNA in routinely processed biopsy and necropsy material and may be used in archival tissues for the diagnosis of infection. Fixation of samples and DNA extraction are, however, crucial steps and require careful control if PCR is used for detection of HCMV, to avoid false negative results.
\end{abstract}

(F Neurol Neurosurg Psychiatry 1993;56:211-214)

HCMVE occurs in up to $30 \%$ of immunocompromised patients and occurs occasionally in immunocompetent hosts as well. ${ }^{1}$ In adults, HCMV infection is increasingly seen as an opportunistic infection complicating the acquired immunodeficiency syndrome (AIDS). Perinatally HCMVE is due mostly to intra-uterine transplacental infection. A characteristic histological feature of cerebral HCMV infection is a periventricularly accentuated necrotising encephalitis with haemorrhage and calcification, but cases with

\section{Material and methods}

We examined six cases of HCMVE (table, cases 1-4 from our Institute, cases 5-6 from the Department of Neuropathology, University of Oxford, UK). All demonstrated typical histological features such as inclusion-bearing cells of Cowdry type A, microglial proliferation, focal parenchymal necroses and lymphocytic infiltration. Six cases with HSV-1 encephalitis and five cases without neuropathological changes were used as controls. Diagnosis was made by routine histological examination and corroborated by immunocytochemistry with a monoclonal antibody (anticytomegalovirus, dilution 1:25, DAKO, Hamburg, Germany) in all cases. Necropsy

Table Clinical and laboratory data of 6 patients with HCMV encephalitis

\begin{tabular}{|c|c|c|c|c|c|c|c|c|c|c|}
\hline \multirow{2}{*}{ Number } & \multirow{2}{*}{ Age/Sex } & \multirow{2}{*}{ AIDS } & \multirow{2}{*}{$\begin{array}{l}\text { Histology } \\
\text { diagnosis }\end{array}$} & \multirow{2}{*}{$\begin{array}{l}\text { Immuno- } \\
\text { cytochemistry }\end{array}$} & \multicolumn{2}{|c|}{$H C M-P C R$} & \multirow[b]{2}{*}{ c } & \multicolumn{2}{|c|}{$\beta$-globin-PCR } & \multirow{2}{*}{$\begin{array}{l}\text { nonspecific } \\
\text { inhibition }\end{array}$} \\
\hline & & & & & $a$ & $b$ & & $a$ & $c$ & \\
\hline Case 1 & 44/Male & + & HCMVE & HCMV-pos & + & $6 / 6$ & nd & nd & nd & No \\
\hline Case 2 & 47/Male & + & HCMVE & HCMV-pos & + & $5 / 5$ & $>10^{2}$ & + & $>10^{3}$ & No \\
\hline Case 3 & 49/Male & + & HCMVE & HCMV-pos & + & $5 / 5$ & $>10^{\prime}$ & + & $>10^{3}$ & No \\
\hline Case 4 & $2 \mathrm{~m} /$ Male & - & HCMVE & HCMV-pos & + & $8 / 8$ & $>10^{4}$ & + & $>10^{4}$ & No \\
\hline Case 5 & 1d/Male & - & HCMVE & HCMV-pos & - & $0 / 7$ & $<10^{\prime}$ & - & $<10^{2}$ & No \\
\hline Case 6 & 50/Male & + & HCMVE & HCMV-pos & id & $1 / 7$ & $<10^{1}$ & - & $<10^{2}$ & No \\
\hline
\end{tabular}

Age in years, case 4 in months, case 5 in days; HCMVE = human cytomegalovirus encephalitis; id $=$ indeterminated; nd = not done $\mathrm{a}=\mathrm{PCR}$ result; $\mathrm{b}=$ number of possible results/number of sections; $\mathrm{c}=$ estimated copy number of target sequences per $5 \mu$ extract. 
brains from our laboratory had been routinely fixed in $6 \%$ buffered formalin for up to three weeks post mortem before dissection and paraffin-embedding. Samples from the Department of Neuropathology, University of Oxford, had been fixed in $10 \%$ buffered formalin. For PCR, paraffin blocks from areas with histologically proven inflammatory changes as well as from remote areas without histological evidence of infection were selected from HCMV and HSV-1 cases. Samples from the periventricular area, which is a predilection site of HCMVE, were chosen for PCR from the control cases.

Sections of paraffin-embedded tissue were processed for PCR according to Wright and Manos. ${ }^{\circ}$ Samples were placed in a $1.5 \mathrm{ml}$ reaction tube and extracted twice with n-octane and twice with absolute ethanol. Remaining ethanol was evaporated completely under vacuum and $200 \mu \mathrm{l}$ per sample of proteinase digestion buffer was added containing (final concentrations) $200 \mu \mathrm{g} / \mathrm{ml}$ Proteinase K (Boehringer Mannheim, Mannheim, Germany), $50 \mathrm{mM}$ Tris $/ \mathrm{HCl} \mathrm{pH} 8.5,1 \mathrm{mM}$ EDTA and $1 \%$ Triton $\mathrm{X}-100$. Proteinase digestion was carried out for three hours at $55^{\circ} \mathrm{C}$, the enzyme was inactivated by boiling the samples for five minutes, and insoluble material was pelleted at $10.000 \mathrm{~g}$ for $10 \mathrm{~min}$ utes. Five $\mu$ l of the supernatants were used in PCR. All samples investigated were extracted and tested by $\mathrm{nPCR}$ at least in duplicate.

PCR was performed as previously described. ${ }^{5}$ A DNA fragment from the coding region of the essential HCMV glycoprotein B $(\mathrm{gB})^{7}$ was amplified using two sets of nested primers $\left(E_{1,2}, I_{1,2} ; E_{1}\right.$ 5'-TCC AAC ACC CAC AGT ACC 'CGT-3', E 5'-CGG AAA CGA TGG TGT AGT TCG-3', I, 5'-GTC AAG GAT CAG TGG CAC AGC-3', I 5' $^{\prime}$-GTA GCT GGC ATT GCG ATT GGT-3'). Primers $\mathrm{E}_{1,2}$ created a $268 \mathrm{bp}$ amplimer, primers $I_{1,2}$ allowed the amplification of a $183 \mathrm{bp}$ fragment located within the external amplimer. PCR was carried out for 30 cycles with the primer pair $E_{1,2}$. Subsequently, $5 \mu \mathrm{l}$ of the reaction mix was transferred to a second reaction mix containing the primer pair $I_{1,2}$, and PCR was continued for another 30 cycles. The final concentrations of reagents were $67 \mathrm{mM}$ Tris/ $\mathrm{HCl}$ pH $8.8, \quad 16.6 \mathrm{mM}$ $\left(\mathrm{NH}_{4}\right)_{2} \mathrm{SO}_{4}, 3 \mathrm{mM} \mathrm{MgCl}{ }_{2}, 0.7 \mathrm{mM} \beta$-mercaptoethanol, $20 \mu \mathrm{g} / \mathrm{ml}$ gelatine, $0 \cdot 1 \mu \mathrm{M}$ external or $1 \mu \mathrm{M}$ internal primers, respectively, $400 \mu \mathrm{M}$ of each $\mathrm{dNTP}$, and 1.25 units taq polymerase (Promega, Heidelberg, Germany). The final reaction volume was adjusted to $50 \mu \mathrm{l}$. Primer annealing occurred at $60^{\circ} \mathrm{C}$ (45 s), DNA synthesis at $72^{\circ} \mathrm{C}(45 \mathrm{~s})$, and denaturation at $94^{\circ} \mathrm{C}(60 \mathrm{~s})$. After PCR samples were separated on $4 \%$ agarose gels and PCR amplimers were visualised by ethidium bromide staining and UV-illumination. The specificity of PCR was controlled by Southern blotting using a digoxigenin-labelled $109 \mathrm{bp}$ DNA probe located within the internal $183 \mathrm{bp}$ PCR amplimer. This DNA probe was obtained with a third set of primers $\left(P_{1,2}, P_{1}\right.$ 5'-CTG GCT CTA TCG TGA GAC CTG-3', $P_{2}$
5'-GTA AAC CAC ATC ACC CGT GGA-3') and directly labelled in PCR by adding digoxigenin-11-dUTP (Boehringer Mannheim) to the reaction mix. Specifically hybridised DNA probe was visualised by chemoluminescence using an alkaline phosphatase-conjugated rabbit anti-digoxigenin antiserum and AMPPD as substrate (Dig Luminescent Detection Kit, Boehringer Mannheim, Germany).

To control the efficiency of DNA extraction, a 105 bp amplimer of the human $\beta$-globin gene $^{8}$ was amplified using the primers $1 \mathrm{a}$ and lb (1a 5'-CTG CCG TTA CTG CCC TGT GG-3'; 1 b 5'-CTA TTG GTC TCC TTA AAC CTG-3'). PCR was performed as described above.

\section{Results}

In four cases of HCMVE DNA fragments of the predicted size were consistently amplified by nPCR (fig A, table). The specificity of the amplified DNA fragments could be demonstrated in Southern blots using a digoxigeninlabelled DNA probe (fig B). Only tissues with histological features of inflammation yielded an amplification of HCMV specific DNA sequences, whereas tissues from remote areas without histological evidence of infection remained negative. In two cases of histologically proven HCMVE, viral DNA could either not be demonstrated by nPCR (patient 5 , table) or was detected only in one of seven extracts tested (patient 6 , table). To investigate these obviously false negative PCR results further, a number of control experiments were performed. Thus all HCMV-PCR negative extracts were tested for the presence of nonspecific inhibitors by adding $10^{\circ}, 10^{1}, 10^{2}, 10^{3}$ and $10^{4}$ copies of linearised, purified plasmid DNA containing the entire HCMV $\mathrm{gB}$ sequence before amplification by PCR. A nonspecific inhibition could not be demonstrated. The detection limit of PCR was estimated to be approximately $10^{1}$ copies of the HCMV gB target sequence. Knowing the approximate detection limit, PCR positive samples were serially diluted to determine the number of target sequences present. The calculated number of HCMV target sequences in nPCR positive samples reached from $>10^{1}$ (patient 3 ) to $>10^{4}$ (patient 4 , table). To exclude false negative PCR results due to HCMV strain variations and resulting primer mismatches, we tested extracts of patients 4,5 , and 6 in nPCR using all possible combinations of primers $\mathrm{E} 1$, E2, I1, I2, P1 and P2. Only sporadic positive results were obtained with extracts of patients $5(2 / 9)$ and $6(1 / 9)$, whereas extracts of patient 4 gave positive results with all primer combinations tested (9/9). No influence of specific primer combinations on the outcome of nPCR could be demonstrated (data not shown). Finally, to control DNA extraction from paraffin-embedded tissues, all samples were tested for the presence of $\beta$-globin target sequences, which is a single copy gene present in all human cells. Using purified plasmid DNA as control, the sensitivity (approximately $10^{2}$ copies) and the number of $\beta$-globin target 


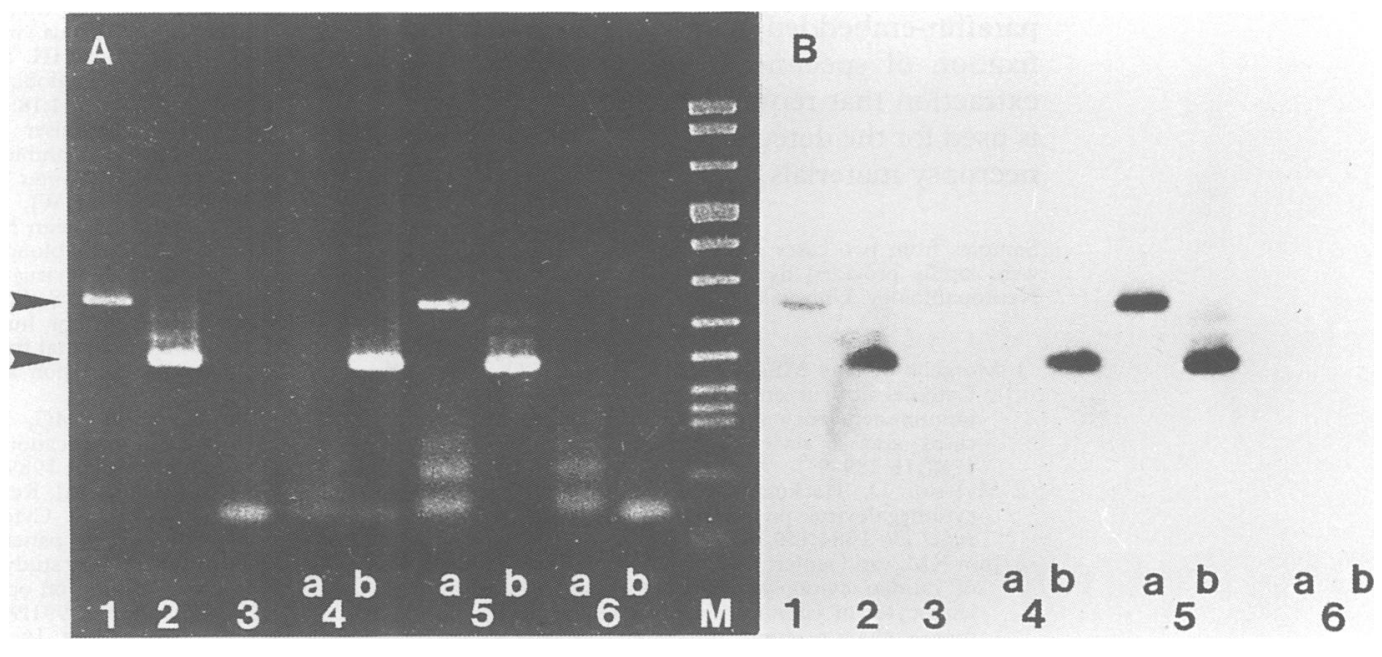

Figure Demonstration of PCR amplified HCMV-DNA. Samples were separated on a 4\% agarose gel and visualised by ethidium bromide staining $(A)$. Subsequently, specifically amplified DNA fragments were identified by Southern blotting and hybridisation with a non-radioactive, digoxigenin-labelled DNA probe $(B)$.

Lanes 1, 2: positive control containing $10 \mathrm{fg}$ purified plasmid DNA amplified with external PCR primers (lane 1) or by nPCR (lane 2), respectively. Lane 3: negative control. Lanes 4-6: individual samples corresponding to case 3 (L4a+b), case $4(L 5 a+b)$, and case $5(L 6 a+b)$ from the table. Extracts from case $3(L 4 a+b)$ contained relatively low amounts of HCMV DNA as compared to extracts from case $4(L 5 a+b)$. Thus, re-amplification of samples with an internal set of primers by nested PCR was necessary to obtain a positive signal (see also table). In case 5 (L6a+b) no HCMV DNA could be amplified.

$M=$ molecular weight markers ( $p U C B M 21 / H p a I I+p U C B M 21 / D r a 1 / H i n d I I)$.

sequences per sample were estimated (as given above). It could be consistently demonstrated, that extracts of HCMVE patients 5 and 6 contained $<10^{2} \beta$-globin copies per $5 \mu \mathrm{l}$ extract. In contrast, the amount of $\beta$-globin sequences in HCMV-PCR positive samples ranged between $10^{3}$ and $10^{4}$ copies per $5 \mu \mathrm{l}$ extract.

None of the control tissues from patients with HSV-1 encephalitis $(n=6)$ or without pathological findings $(n=5)$ contained detectable amounts of HCMV DNA (data not shown).

\section{Discussion}

PCR has been used to detect HCMV DNA in a variety of clinical specimens, such as peripheral blood, ${ }^{310}$ urine, ${ }^{11}$ saliva, ${ }^{12}$ and formalinfixed paraffin-embedded surgical biopsies or necropsy samples. ${ }^{1314}$ Our present findings confirm that PCR can also be used to detect HCMV virus in paraffin sections from human necropsy brains. Necropsy material stored for several years still seems to be suitable for detection of viral genomic DNA sequences. The use of a nested PCR protocol offers maximum sensitivity and specificity. In four cases of HCMVE from our laboratory, we could readily amplify HCMV specific sequences (fig, table). We could, however, only detect CMV specific DNA sequences in tissues with histological features of inflammation or infection, not in areas remote from inflammatory foci. It seems to be mandatory therefore to use samples from regions with inflammatory changes, especially if the sample is small, for example in a sterotactic biopsy.

In two cases of immunocytochemically proven HCMVE from a different Institute,
HCMV specific DNA sequences could only sporadically be amplified (fig, table). However, immunocytochemical investigations clearly demonstrated, that these tissues contained viral antigens. Since a non-specific inhibition could be excluded and both samples contained significantly lower amounts of $\beta$-globin sequences compared with HCMV-PCR positive samples, the obviously false negative results were most likely due to inefficient DNA extraction or degradation of viral DNA templates. Recently, it has been shown that the fixation protocol for materials used in PCR is a crucial step, since some fixation methods damage DNA and thus deleteriously affect subsequent PCR analysis. ${ }^{15}{ }^{16}$ An appreciable degradation of longer DNA templates occurs in formalin fixed materials. Therefore short amplimers $<300 \mathrm{bp}$ are desirable.

As HCMV is an important clinical pathogen in the immunocompromised host causing significant morbidity and mortality, the development of new diagnostic procedures is urgently needed for the early detection of opportunistic infection. HCMV visceral infection is a major cause of morbidity in AIDS patients and HCMVE has been found in $15-30 \%$ of HIVpatients in several large necropsy series. ${ }^{17}$ Investigation of prevalence and incidence of HCMV infection of the CNS is important, because patients with HCMVE may benefit from a therapy with ganciclovir or foscarnet. In AIDS patients HCVM infection may mimic HIV-encephalitis or may be masked by concurrent opportunistic viral and non-viral CNS lesions. Therefore PCR may offer an additional diagnostic tool, especially if only small samples (for example, by stereotactic biopsy) are available. Our results confirm that PCR can be used as a specific diagnostic method to detect 
HCMV DNA sequences in formalin-fixed, paraffin-embedded materials. Critical steps are fixation of specimens and subsequent DNA extraction that require careful control, if PCR is used for the detection of HCMV in biopsy or necropsy materials.

Samples from two cases of HCMVE (Cases 5 and 6, Table) were kindly provided by Dr Margaret Esiri, Department of Neuropathology, University of Oxford, UK.

1 Morgello S, Cho MS, Nielsen S, Devinsky O, Petito CK Cytomegalovirus encephalitis in patients with acquired immunodeficiency syndrome: an autopsy study of 30 cases and a review of the literature. Hum Pathol 1987;18:289-97.

2 Myerson D, Hackman RC, Meyers JD. Diagnosis of cytomegalovirus pneumonia by in situ hybridization. $\mathcal{f}$ cytomegalovirus pneumo

3 Jiwa NM, van Gemert GW, Raap AK, et al. Rapid detection of human cytomegalovirus DNA in peripheral blood leukocytes of viremic transplant recipients by the polymerase chain reaction. Transplantation 1989;48:72-76.

4 Nicoll JAR, Maitland NJ, Love S. Use of the polymeras chain reaction to detect herpes simplex virus DNA in paraffin sections of human brain at necropsy. $\mathcal{f}$ Neurol Neurosurg Psychiatry 1991;54:167-8.

5 Kühn JE, Schäfer P, Gutbrod $P$, Möhring $K$, Bartel J, Schmitt B, Braun RW. Detection of HCMV-DNA in clinical samples by polymerase chain reaction, comparison with routine diagnostic procedures for the demonison with routhe diagnostic proced in recipients. Biotest Bull 1991;4:309-15.

6 Wright DK, Manos MM. Sample preparation from paraffin-embedded tissues. In: Innis MA, Gelfand $\mathrm{DH}$, Sninsky JJ, White TJ, eds. PCR protocols. San Diego: Academic Press 1990:153-8.

7 Cranage MP, Kouzarides T, Bankier $\mathrm{AD}$, et al. Identification of the human cytomegalovirus glycoprotein B gene and induction of neutralizing antibodies via its expression in recombinant vaccinia virus. $E M B O \mathcal{f}_{1986}$ 198:3057-63.

8 Orkia SH, Kazazian HH. The mutation and polymorphism of the human beta-globin gene and its surroudning DNA. Ann Rev Genet 1984;18:131-71.

9 Porter-Jordan K, Keiser J, Garret CT. Interfering substances that cause inhibition in polymerase-chain reaction PCR) assays. Fresenius $f$ Anal Chem 1990;337:119.

10 Shibata D, Martin WJ, Appleman MD, Causey DM, Leedom JM, Arnheim N. Detection of cytomegalovirus DNA in peripheral blood of patients infected with human immunodeficiency virus. $\mathcal{F}$ Infect $D$ is $1988 ; 158: 1185-92$.

11 Olive DM, al Mufti S, Simsek M, Fayez H, al Nakib W. Direct detection of human cytomegalovirus in urine specimens from renal transplant patients following polymerase chain reaction amplification. 7 Med Virol 1989; 29:232-7.

12 Cassol SA, Poon MC, Pal R, et al. Primer-mediated enzymatic amplification of cytomegalovirus (CMV) DNA. J Clin Invest 1989;83:1109-15.

13 Burgart LJ, Heller MJ, Reznicek MJ, Greiner TC, Teneyck CJ, Robinson RA. Cytomegalovirus detection in bone marrow transplant patients with idiopathic pneumonitis. marrow transplant patients with idiopathic pneumonitis. ase chain reaction on open lung biopsy specimen tissue. ase chain reaction on open lung

14 Persons DL, Moore JA, Fishback JL. Comparison of polymerase chain reaction, DNA in situ hybridization, and histology with viral culture to detect cytomegalovirus in immunosuppressed patients. Mol Pathol 1991;4: 149-53.

15 Rogers BB, Alpert LC, Hine EAS, Buffone GJ. Analysis of DNA in fresh and fixed tissue by the polymerase chain reaction. Am f Pathol 1990;136:541-8.

16 Greer CE, Lund JK, Manos MM. PCR amplification from paraffin-embedded tissues: recommendations on fixatives for long-term storage and prospective studies. PCR Methods Applications 1991;1:46-50.

17 Lang W, Miklossy J, Deruaz JP, et al. Neuropathology of the acquired immune deficiency syndrome (AIDS): a report of 135 consecutive autopsy cases from Switzerland. Acta Neuropath 1989;77:379-90. 